\title{
PRODUCTION AND TENDENCY IN MILK PROCESSING IN MONTENEGRO
}

\author{
Miljan Joksimovićl, Sanjin Ivanović ${ }^{2}$, Svjetlana Janković Šoja ${ }^{3}$ \\ *Corresponding authorE-mail: miljanj@ucg.ac.me
}

\begin{abstract}
A R T I C LE I N F O
A B S T R A C T

Original Article

Production and processing of milk represents a

Received: 09 March 2020

very important sector of the agricultural industry of

Accepted: 08 May 2020

Montenegro. Milk production is performed primarily on family farms, from which a small percentage is further doi:10.5937/ekoPolj2002391J

UDC 637.1(497.15) placed in processing facilities. In addition to favourable conditions for cattle rearing and milk production, production results are modest. ARIMA model was applied

Keywords:

Milk, production, procession, investments, seasonal ARIMA models in order to forecast the quantities of cow's milk that will be collected and processed in 2019 into fermented dairy products and drinking milk. The observed and obtained data show the presence of seasonal and trend component in time series. Furthermore, the analysis highlighted the

JEL: C22, Q12, Q13 importance of milk processing on family farms, in addition to the need for investment in its improvement. The paper also analyzes investment support referring to the milk processing facilities in Montenegro.
\end{abstract}

(C) 2020 EA. All rights reserved.

\section{Introduction}

At the global level, livestock represents a significant sector of agriculture. Products obtained through certain lines of livestock production (milk, meat, etc.) participate in the daily nutrition of the population. Milk comprises a huge and irreplaceable importance in providing essential ingredients in the human nutrition, as one of the main sources of protein. Global protein consumption through dairy products accounts for $10.3 \%$ of total protein intake (Deshmukh, Paramasivam, 2016). Milk and dairy products are characterized by a very important role in the structure of nutrition (Jovanović et

1 Miljan Joksimović, Mr. Sci., Teaching Assistant, Biotechnical faculty, University of Montenegro, Mihaila Lalića 15, 81000 Podgorica, Montenegro, +382 (20) 268 435, miljanj@ucg.ac.me, ORCID ID (https://orcid.org/0000-0002-1188-7677)

2 Sanjin Ivanović, Ph.D., Associate Professor, Faculty of Agriculture, University of Belgrade, Nemanjina 6 street, +381 (11) 4423 426, sanjinivanovic@agrif.bg.ac.rs, ORCID ID 00000002-2005-9910

3 Svetlana Janković Šoja, Ph,D, Assistant Professor, Faculty of Agriculture, University of Belgrade, Nemanjina 6 street, +381 (60) 5549 604, svjetlanajs@agrif.bg.ac.rs, https://orcid. org/0000-0002-5474-9039

http://ea.bg.ac.rs 
al., 2001). As such, in addition to certain cereals, milk is the most important agrifood product; therefore, a special attention is paid to the production of milk and dairy products. In this regard, milk production on farms in EU countries is increasing year after year. The leading EU milk producer is Germany, followed by France, the United Kingdom, the Netherlands, Poland, Italy and Spain, producing a total of three quarters of all volume of milk at the EU level. (Eurostat, 2019).

The safety and availability of fodder significantly affects the overall development of livestock. It is necessary that the volume, range and quality of fodder is to be matched with the need for fodder resulting from the number of animal units, structure of production and production capacity of the livestock. Perennial meadows and pastures imply a dominant place in the total agricultural area of Montenegro, and therefore the most important resource in the production of the fodder. Exploitation of meadows and pastures makes it possible to reduce the fodder cost relative to fodder produced on arable land, moreover to reduce a risk of changes in the cost of fodder, primarily maize (Ivanović, 2018).

Due to favourable natural conditions and long tradition, the most important role in the field of agriculture of Montenegro refers to the livestock, with the milk production dominating on the subject of the cattle production. Lactation milk and milk composition are considered to be racial traits, regardless of the existence of extremes in milk yield and composition. (Perišić et al., 2011). However, the racial composition of cattle is quite unfavourable, in view of the fact that various beef crossbreds make up about $46 \%$ of the total population. Highly productive breeds (holstein, brown, simmental and tyrolean gray) collectively account for about $53 \%$. Bush as an indigenous race is represented by $1 \%$ and has its significance as a genetic resource. (Ministry of Agriculture and Rural Development, 2015). Changing racial composition goes towards increasing the participation of more productive races and reducing the participation of beef crossbred.

The main activity of cattle farms is production of milk and dairy products. In Montenegro, on average, 175 million litres of milk have been produced annually in the last decade and a half. Cow's milk accounts for $94 \%$ of total milk production. It is essential to bear in mind that the success of production in the market system of economy entails continuous monitoring, analysis and forecasting of both the business results and determinants that conditioned achieved results. State analysis and prediction may be based on an ordered series of data at equal time intervals, or on the analysis of time series of observed phenomena. If forecasting is the goal of time series analysis, it is based on the available historical data on the basis of which a time series model is formulated and evaluated, which is then used to predict future series values (Novković, 2010).

Autoregressive Integrated Moving Average Process (ARIMA) was used in a number of agricultural researches. Thus, the authors (Farhan et al., 2011) forecasted milk production in Pakistan using the ARIMA model. In order to further empower all participants in the Tamil Nadu milk production chain (Sankar and Prabakaran, 2012), they used the ARIMA model to forecast future milk production. This model was used by both Deshmukh and Paramasivam (2016) and Safa Abdelgadier et al. (2018) to forecast 
milk production. Novković et al. (2010) used ARIMA to forecast the production of certain types of vegetables in Vojvodina. Mutavdžić et al. (2016), using the ARIMA model, predicted prices and price parities of wheat and maize in Serbia. Mihailović et al. (2019) forecasted the prices of the most important vegetable crops (beans, tomatoes, peppers, onions, cabbages and watermelons) in Serbia, also using the ARIMA model.

The aim of this research is to predict quantities of milk that will be collected and processed in milk processing facilities not located within the family farms in Montenegro. In order to achieve this, the ARIMA model was applied using monthly data on quantities of raw cow milk purchased from the beginning of 2013 to the end of 2018. Also, the purpose of the analysis is to assess the need for investment in dairy processing on family farms.

\section{Materials and methods}

In order to observe current situation in milk processing, data from the Statistical Office of Montenegro were used. Data were processed using SPSS 23.0 statistical programme. Monthly data on cow's milk collected, data on obtained quantities of fermented milk products and data on obtained quantities of drinking milk in Montenegro for the period January 2013 - December 2018 were analyzed. Using the Box-Jenkins modelling strategy, the ARIMA models were identified that best describe dynamics of the observed phenomena. The general form of the ARIMA model is as follows (Mladenović, Nojković, 2015):

$$
\left(1-\phi_{1} L-\phi_{2} L^{2}-\cdots-\phi_{p} L^{p}\right)(1-L)^{d} X_{t}=\theta_{0}+\left(1-\theta_{1} L-\theta_{2} L^{2}-\cdots-\theta_{q} L^{q}\right) e_{t}
$$

where $p$ is the order of the autoregressive component, $d$ is the level of model integration, and $q$ is the order of the moving average component, $\phi_{1}, \phi_{2}, \phi_{p}$ represent the autoregressive parameters, $\theta_{0}, \theta_{1}, \theta_{2}, \ldots \theta_{q}$ represent the parameters of the moving average model, and $e_{t}$ is the white noise process. The Box-Jenkins modelling strategy is an iterative procedure that involves three stages (Mladenović, Nojković, 2015). During the first phase, the model is identified, where the researcher firstly determines whether the time series has a stable variance, then decides on the order of integration of the model, and subsequently on the order of the autoregressive and moving average components, and whether a free member is included in the model or not . In the next phase, the parameters of the model are evaluated, followed by the phase of checking the adequacy of the model, which involves checking normality and non-correlation of the residuals. Gujarati (2003) also mentions the fourth stage, which is related to forecasting a value of the observed phenomenon in the future period, based on the evaluated and tested the ARIMA model. He notes that the ARIMA models are gaining popularity precisely because of the higher reliability of forecast values than traditional econometric models.

Following the estimated ARIMA models, quantities of collected milk, fermented milk products and drinking milk produced for the January-December 2019 period were forecasted. 
Agricultural production is characterized by certain seasonal fluctuations, caused by the most common effects of natural and market factors, which also affect the final production results. Seasonal ARIMA models represent special cases of the ARIMA models. Seasonal time series are characterized by periodic fluctuations that recur at intervals of up to one year. The minimum time period in which the observed occurrence is repeated is called the season period and is denoted by $s$. If monthly series are concerned then the season period is equal to 12 , for quarterly series $s=4$ and for semi-annual $s=$ 2 (Kovačić, 1995). Sanchez et al. (2014), analyzing monthly milk production data for a period of ten years, also noted presence of a seasonal component in production, and used the seasonal ARIMA model to forecast milk production.

\section{Results and Discussions}

Observing agricultural farms according to the manner of the usage of agricultural land, $83 \%$ of the total number of farms uses perennial meadows and pastures (Statistical Office, 2016). Hay yield on meadows account 2,53 t/ha on average, whilst regarding the pastures it varies between $0,33-0,74 \mathrm{t} /$ ha. Forage crops of clover and alfalfa in 2017 were $6,40 \mathrm{t} /$ ha of clover and alfalfa $6,10 \mathrm{t} / \mathrm{ha}$.

Of the total number of farms in 2016, 71,38\% reared livestock. The largest share in the structure with $70,18 \%$ is cattle-rearing farms, where 89.269 animal units are raised, of which 59.583 are dairy cows. Sheep-raising farms account for $17,64 \%$ of the total number of farms. The total number of sheep on farms is 191.992, of which 95.243 are used for milking, 10,76\% of farms are engaged in goat breeding, raising 31.458 goats, of which 21.429 are for milking (Statistical Office, 2016). The number of agricultural farms based on the number of animal units they raise, is shown in Table 1. The data presented were obtained on the basis of a conducted survey on the structure of agricultural farms in Montenegro in 2016 by the Statistical Office, and for the needs of the FSS (Farm structure survey).

Table 1. Farms in Montenegro raising cattle by size of herd in 2016

\begin{tabular}{|c|c|c|c|c|c|c|c|c|}
\hline \multirow{2}{*}{$\begin{array}{c}\text { Number of } \\
\text { agricultural } \\
\text { farms }\end{array}$} & \multirow{2}{*}{$\begin{array}{c}\text { Without } \\
\text { cattle }\end{array}$} & \multicolumn{6}{|c|}{ Size of the class according to the number of cattle } \\
\cline { 3 - 9 } & & $\begin{array}{c}\mathbf{1 - 2} \\
\text { units }\end{array}$ & $\begin{array}{c}\mathbf{3 - 9} \\
\text { units }\end{array}$ & $\begin{array}{c}\mathbf{1 0 - 1 9} \\
\text { units }\end{array}$ & $\begin{array}{c}\mathbf{2 0 - 2 9} \\
\text { units }\end{array}$ & $\begin{array}{c}\mathbf{3 0 - 4 9} \\
\text { units }\end{array}$ & $\begin{array}{c}\mathbf{5 0 - 9 9} \\
\text { units }\end{array}$ & $\begin{array}{c}\mathbf{1 0 0} \text { units } \\
\text { and more }\end{array}$ \\
\hline 43.791 & 21.852 & 11.684 & 8.512 & 1.444 & 179 & 76 & 32 & 12 \\
\hline
\end{tabular}

Source: Statistical Office, Structure of agricultural farms in 2016

Table 1 shows that within the cattle-rearing farms, 53\% farms have 1-2 animal units, while the share of farms with 100 or more animal units is only $0,05 \%$. Table 2 . presents data on the number of cows and the production of cow's milk in Montenegro in the period 2013-2018. 
Table 2. Numbers of cows and production of milk in Montenegro for period 2013-2018

\begin{tabular}{|c|c|c|c|c|c|c|c|c|c|c|}
\hline \multirow{3}{*}{ Year } & \multicolumn{4}{|c|}{ Number of cows } & \multicolumn{6}{|c|}{ Milk } \\
\hline & \multicolumn{2}{|c|}{ Cows } & \multicolumn{2}{|c|}{ Dairy cows } & \multirow{2}{*}{$\begin{array}{l}\text { Total } \\
(\mathbf{0 0 0}) ~ I\end{array}$} & \multirow{2}{*}{$\begin{array}{c}\text { Base } \\
\text { index }\end{array}$} & \multirow{2}{*}{$\begin{array}{l}\text { Cow's } \\
(000) \text { I }\end{array}$} & \multirow{2}{*}{$\begin{array}{c}\text { Base } \\
\text { index }\end{array}$} & \multirow{2}{*}{$\begin{array}{c}\text { Per } \\
\text { dairy } \\
\text { cow - I }\end{array}$} & \multirow{2}{*}{$\begin{array}{l}\text { Base } \\
\text { index }\end{array}$} \\
\hline & Total & $\begin{array}{l}\text { Base } \\
\text { index }\end{array}$ & Total & $\begin{array}{l}\text { Base } \\
\text { index }\end{array}$ & & & & & & \\
\hline 2013 & 61.830 & 100,0 & 60.998 & 100,0 & 181.876 & 100,0 & 168.540 & 100,0 & 2.763 & 100,0 \\
\hline 2014 & 63.889 & 103,3 & 63.097 & 103,4 & 191.801 & 105,5 & 178.121 & 105,7 & 2.805 & 101,5 \\
\hline 2015 & 63.262 & 102,3 & 62.812 & 102,9 & 183.086 & 100,7 & 170.701 & 101,3 & 2.710 & 98,1 \\
\hline 2016 & 60.040 & 97,1 & 59.583 & 97,7 & 180.550 & 99,3 & 168.037 & 99,7 & 2.803 & 101,4 \\
\hline 2017 & 60.609 & 98,0 & 60.042 & 98,4 & 181.498 & 99,8 & 169.351 & 100,5 & 2.784 & 100,8 \\
\hline 2018 & 59.859 & 96,8 & 59.469 & 97,5 & 181.509 & 99,8 & 168.235 & 99,8 & 2.792 & 101 \\
\hline
\end{tabular}

Source: Statistical Office 2018, 2019

In the observed period, the number of dairy cows increased in 2014 and 2015, with a slight decrease compared to the base year of 2013. The largest number of cows was recorded in 2014. The production of cow's milk is increasing compared to the base year of 2013, reaching its maximum in 2014, after which a decline is recorded in the following years. The production of milk per cow was also the highest in 2014, after which it declined, which is very unfavourable and indicates stagnation regarding the racial composition of the cows and the level of milk production technology itself.

Most non-family-owned milk processing facilities in Montenegro have implemented HACCP and other relevant standards. The volume of dairy production in their product range is dominated by fermented dairy products, drinking milk, cheese made exclusively from cow's milk and cream. Namely, the dairy industry in Montenegro is characterized by a narrow range of products (mainly yogurt, sour cream and various types of hard and soft cheeses and sweet (short-lived) milk and whey). Of the 25 processors in 2015, 5 produced sweet (short-lived) milk, 5 whey, 12 different types of cheese and 5 produced yoghurt. However, among the 5 dairies whose dominant product is yogurt, 4 are the largest, which together process $63 \%$ of purchased milk, leading to the conclusion that yogurt is the prevailing product in the dairy product range of Montenegro (Ministry of Agriculture and Rural Development, 2015).

The analysis of the purchase of the largest milk processors leads to the conclusion that the most produced milk is produced $(59 \%)$ and processed $(75 \%)$ in the central region of Montenegro. In the northern region 32\% of purchased milk is produced and $22 \%$ is processed, while in the coastal region $9 \%$ is produced and only $3 \%$ is processed. Total quantities of cow's milk purchased in the period January 2013 - December 2018 ranged from $11-15 \%$ of total cow's milk produced in Montenegro, which indicates that a large part of the produced milk remains on family farms and is processed thereof.

The chemical and hygienic quality of raw milk in Montenegro is provided in (Table 3). From the above data on the chemical and hygienic quality of raw milk, it can be seen that chemical quality is improving year after year. 
Table 3. Overview of the milk quality in Montenegro for period 2013-2017

\begin{tabular}{|c|c|c|c|c|}
\hline Year & Fat $(\%)$ & Proteins (\%) & $\begin{array}{c}\text { Number of somatic } \\
\text { cells } \times 1000\end{array}$ & $\begin{array}{l}\text { Total number of } \\
\text { bacteria x } 1000\end{array}$ \\
\hline 2013 & 3,98 & 3,26 & 663 & 4.036 \\
\hline 2014 & 3,99 & 3,26 & 636 & 3.179 \\
\hline 2015 & 4,02 & 3,23 & 543 & 2.556 \\
\hline 2016 & 4,04 & 3,24 & 504 & 2.376 \\
\hline 2017 & 4,07 & 3,22 & 470 & 1.907 \\
\hline
\end{tabular}

Source: Ministry of Agriculture and Rural Development, 2018

According to data from the Directorate for Food Safety, Veterinary and Phytosanitary Affairs of Montenegro, in 2017 (from farms under the official control system for milk production and processing), 2.000 producers delivered milk to milk processing facilities, while 1.000 producers processed milk on their own farm into cheese and cream intended for the market. Given the fact that most of the milk produced is processed on farms, it is clear that small milk producers sell their production to dairies, while those larger producers are more oriented towards processing milk on their own farms.

\section{Analysis and forecast of the quantity of cow's milk collected}

In the analyzed period from January 2013 to December 2018, the average amount of cow's milk collected was $2.152 .933,1 \mathrm{~kg}$. The minimum amount of milk collected was $1.720 .616 \mathrm{~kg}$, obtained in February 2016, while the largest amount collected in July 2018 was $2.613 .105,9 \mathrm{~kg}$. In the observed period, the trend of increase in the collected quantities of cow's milk is present during the period from February to July-August for each year, followed by a decrease in the collected quantities. This refers to the presence of a seasonal component. Such drift of the quantity of milk collected is conditioned by the volume of milk production on farms. Greater milk production is related to the quality of livestock nutrition, that is, to pasture use in summer.

Tendencies in the drift of collected cow's milk quantities in the observed period, in addition to the forecasted quantities are shown in Graph 1. Table 4. shows the parameters of the estimated model for the forecast of cow's milk collected. The estimated model forecasts quantities for the period January-December 2019 (Table 5). The estimated ARIMA model of cow's milk collected shows that the movement of production of the current month is significantly influenced by the quantities of collected milk from the same month of the previous year, which is in accordance with the biological and technical and technological characteristics of this production.

Table 4. Estimated parameters of ARIMA $(0,1,0) \times(1,0,0)$ models for variable of collected cow's milk

\begin{tabular}{|l|r|c|c|c|c|c|}
\hline Variable & \multirow{2}{*}{ Parameters } & \multirow{2}{*}{$\begin{array}{c}\text { Standard } \\
\text { Error }\end{array}$} & \multirow{2}{*}{$\mathbf{t}$ - ratio } & \multirow{2}{*}{$\mathbf{p}$} & \multicolumn{2}{|c|}{$\mathbf{9 5 \% \text { confidence interval }}$} \\
\cline { 6 - 7 } & & & & Lower & Upper \\
\hline SAR $(1)$ & 0,666322 & 0,108100 & 6,163954 & 0,000000 & 0,450724 & 0,881920 \\
\hline
\end{tabular}

Source: Authors' calculations 
Table 5. Projected quantities of cow's milk collected in Montenegro for the period JanuaryDecember 2019 based on ARIMA $(0,1,0) \times(1,0,0)_{12}$

\begin{tabular}{|l|r|r|r|r|r|}
\hline \multirow{2}{*}{ Month } & \multirow{2}{*}{$\begin{array}{c}\text { Projected } \\
\text { quantities }\end{array}$} & \multicolumn{2}{|c|}{$\begin{array}{c}\text { 90\% confidence interval of } \\
\text { projected volume }\end{array}$} & \multirow{2}{*}{$\begin{array}{c}\text { Standard } \\
\text { error of the } \\
\text { forecast }\end{array}$} & \multirow{2}{*}{\begin{tabular}{c}
\multirow{2}{*}{ Quantity } \\
collected
\end{tabular}} \\
\cline { 3 - 4 } & & Lower limit & \multicolumn{1}{c|}{ Upper limit } & \\
\hline January 2019 & 2.111 .736 & 1.953 .376 & 2.270 .095 & $95.001,6$ & 2.078 .011 \\
\hline February 2019 & 2.035 .791 & 1.811 .837 & 2.259 .746 & $134.352,6$ & 1.994 .351 \\
\hline Mach 2019 & 2.197 .822 & 1.923 .535 & 2.472 .108 & $164.547,6$ & 2.214 .211 \\
\hline April 2019 & 2.247 .734 & 1.931 .015 & 2.564 .453 & $190.003,2$ & 2.243 .693 \\
\hline May 2019 & 2.395 .280 & 2.041 .177 & 2.749 .383 & $212.430,1$ & 2.513 .963 \\
\hline June 2019 & 2.363 .612 & 1.975 .712 & 2.751 .512 & $232.705,5$ & 2.479 .166 \\
\hline July 2019 & 2.406 .006 & 1.987 .026 & 2.824 .986 & $251.350,6$ & 2.573 .433 \\
\hline August 2019 & 2.357 .145 & 1.909 .236 & 2.805 .053 & $268.705,1$ & 2.621 .857 \\
\hline September 2019 & 2.265 .587 & 1.790 .509 & 2.740 .666 & $285.004,8$ & 2.459 .134 \\
\hline October 2019 & 2.243 .744 & 1.742 .967 & 2.744 .521 & $300.421,5$ & 2.387 .715 \\
\hline November 2019 & 2.122 .012 & 1.596 .793 & 2.647 .232 & $315.084,7$ & \\
\hline December 2019 & 2.094 .874 & 1.546 .300 & 2.643 .447 & $329.095,2$ & \\
\hline
\end{tabular}

Source: Authors' calculations

It can be seen from Table 5. that the standard error of the forecast increases with the increase in the number of periods for which the cow's milk is forecasted. With the passage of time, the differences are percentage-wise increasing between forecast and actual values. This result is expected because the model does not capture all future events that may affect the observed variable.

Figure 1. Tendencies of observed and forecasted quantities of cow's milk collected

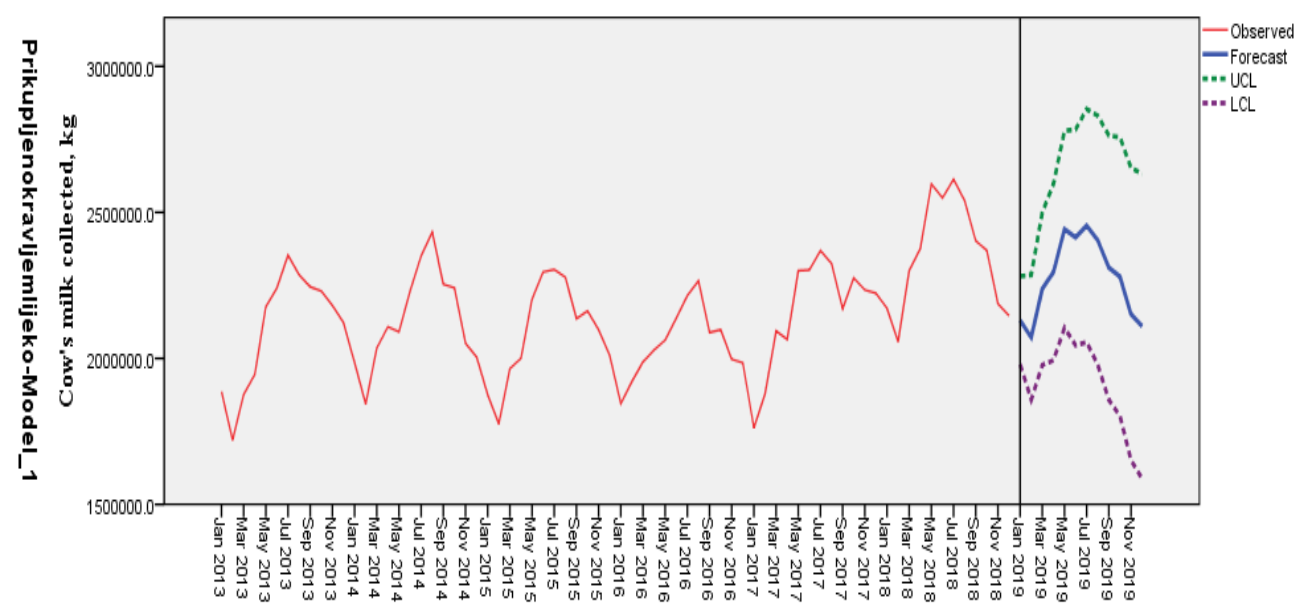

Source: Authors' calculations 


\section{Analysis and forecast of production of fermented dairy products}

Fermented dairy products have the largest share in the structure of products obtained from milk processing in processing facilities. The average quantity produced of these products for the period January 2013- December 2018 was $679.123 \mathrm{~kg}$. In December $2014,459.199 \mathrm{~kg}$ of fermented dairy products were produced and this is the lowest amount obtained for the observed period. The largest production volume was obtained in August 2018 in the amount of 1.020.673,5 kg. Production of this product group in the period 2013-2015 had a trend of growth from February to August, while for the period 2016-2018, the growth trend recorded from January to August. For both periods, production is declining after the month of August.

Referring to the fermented dairy products, there is a trend and a seasonal component. Graph 2. shows the obtained and forecasted quantities in the production of fermented dairy products. Table 6 . shows the parameters of the estimated model for forecasting the production of fermented dairy products. The estimated model forecasts quantities for the period January-December 2019 (Table 7). The estimated ARIMA model of fermented dairy production shows that the volume of fermented dairy products from the same month of the previous year is significantly influenced by the current month's production trends.

Table 6. Estimated parameters of $\operatorname{ARIMA}(0,1,0) \times(1,0,0){ }_{12}$ models for variable of production of fermented dairy products

\begin{tabular}{|l|r|r|r|r|r|r|}
\hline Variables & \multirow{2}{*}{ Parameters } & \multirow{2}{*}{$\begin{array}{c}\text { Standard } \\
\text { Error }\end{array}$} & \multirow{2}{*}{$\mathbf{t}$-ratio } & \multirow{2}{*}{$\mathbf{p}$} & \multicolumn{2}{|c|}{$\mathbf{9 5 \%}$ confidence interval } \\
\cline { 6 - 7 } & & & & \multicolumn{1}{|c|}{ Lower } & \multicolumn{1}{c|}{ Upper } \\
\hline $\mathrm{AR}(1)$ & $-0,315460$ & 0,121597 & $-2,59430$ & 0,011567 & $-0,558040$ & $-0,072880$ \\
\hline $\mathrm{SAR}(1)$ & 0,639109 & 0,121846 & 5,24521 & 0,000002 & 0,396033 & 0,882186 \\
\hline
\end{tabular}

Source: Authors' calculations

Table 7. Projected quantities of fermented dairy products in Montenegro for the period January-December 2019 based on ARIMA $(0,1,0) \times(1,0,0)_{12}$

\begin{tabular}{|c|c|c|c|c|c|}
\hline \multirow[t]{2}{*}{ Month } & \multirow{2}{*}{$\begin{array}{l}\text { Projected } \\
\text { quantities }\end{array}$} & \multicolumn{2}{|c|}{$\begin{array}{c}90 \% \text { confidence interval of } \\
\text { projected volume }\end{array}$} & \multirow{2}{*}{$\begin{array}{l}\text { Standard } \\
\text { error of the } \\
\text { forecast }\end{array}$} & \multirow{2}{*}{$\begin{array}{l}\text { Quantity } \\
\text { collected }\end{array}$} \\
\hline & & Lower limit & Upper limit & & \\
\hline January 2019 & $718.685,5$ & $609.651,4$ & 827.720 & $65.398,0$ & 635.804 \\
\hline February 2019 & $726.930,8$ & $594.797,1$ & 859.064 & $79.253,0$ & 717.971 \\
\hline Mach 2019 & $762.190,1$ & $604.812,7$ & 919.567 & $94.394,0$ & 765.196 \\
\hline April 2019 & $818.916,4$ & $641.427,2$ & 996.406 & $106.457,0$ & 787.202 \\
\hline May 2019 & $872.941,9$ & $676.942,9$ & 1.068 .941 & $117.559,1$ & 787.579 \\
\hline June 2019 & $848.286,7$ & $635.513,9$ & 1.061 .060 & $127.619,9$ & 924.869 \\
\hline July 2019 & $911.431,3$ & $683.074,6$ & 1.139 .788 & $136.967,0$ & 1.091 .010 \\
\hline August 2019 & $977.112,3$ & $734.180,9$ & 1.220 .044 & $145.708,8$ & 1.005 .789 \\
\hline September 2019 & $836.859,1$ & $580.175,9$ & 1.093 .542 & $153.957,1$ & 817.051 \\
\hline October 2019 & $831.950,5$ & $562.216,7$ & 1.101 .684 & $161.784,8$ & 745.730 \\
\hline November 2019 & $779.515,7$ & $497.333,9$ & 1.061 .698 & $169.251,0$ & - \\
\hline December 2019 & $779.934,2$ & $485.830,8$ & 1.074 .038 & $176.401,5$ & - \\
\hline
\end{tabular}

Source: Authors' calculations 
Figure 2. Tendencies in production of observed and forecasted quantities of fermented dairy products

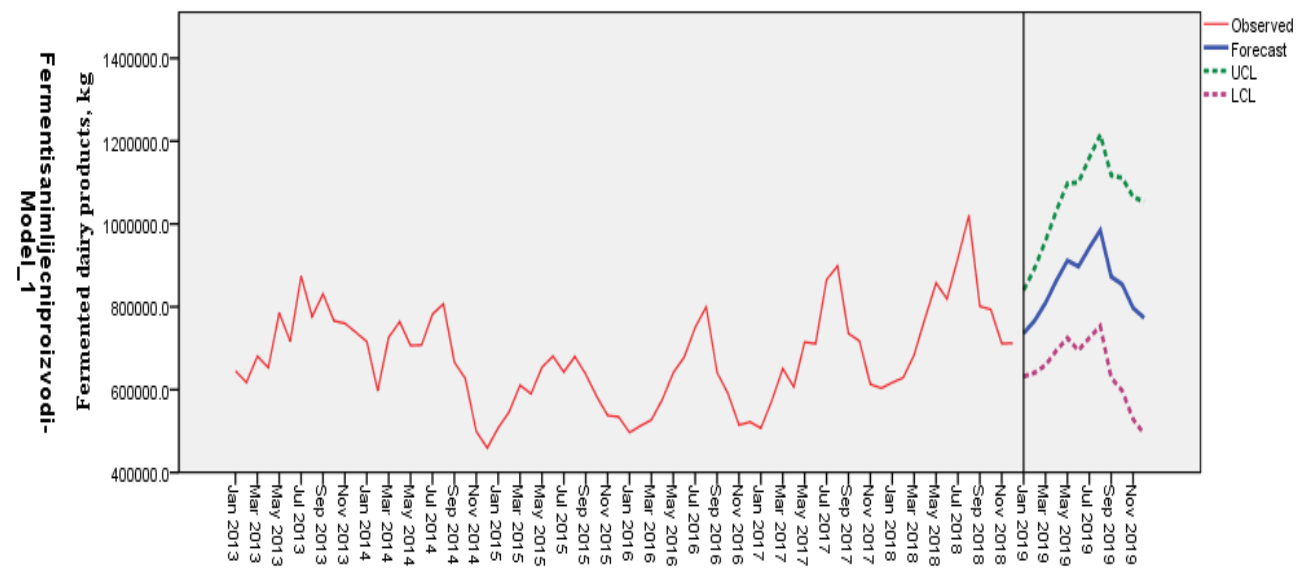

Source: Authors' calculations

\section{Analysis and forecast of production of drinking milk}

The average quantity of drinking milk produced in the period January 2013- December 2018 was $503.015 \mathrm{~kg}$. Production of drinking milk from the beginning of 2013 to the end of 2014 was increasing, with minor fluctuations in the second half of 2013. In 2014, the largest production was recorded in the amount of $824.408 \mathrm{~kg}$. Since January 2015 , there was a constant downward trend in production, which resulted in the smallest production in December 2018 amounting to $284.348 \mathrm{~kg}$.

The graphical presentation of the trend in the production of drinking milk (Graph 3) confirms notable trends in production in the analyzed period, in addition to more stable production in the forecast period. Table 8 . shows the parameters of the estimated model for drinking milk production. The estimated model forecasted quantities of drinking milk for the period January-December 2019 (Table 9). The estimated ARIMA model of drinking milk produced shows that the drift of production of the current month significantly influences the volume of drinking milk produced in the same month of the previous year.

Table 8. Estimated parameters of $\operatorname{ARIMA}(1,1,0) \times(1,0,0)_{12}$ models for the variable production of drinking milk

\begin{tabular}{|l|r|r|r|r|r|r|}
\hline Variables & \multirow{2}{*}{ Parameters } & \multirow{2}{*}{$\begin{array}{c}\text { Standard } \\
\text { Error }\end{array}$} & \multirow{2}{*}{ t-ratio } & \multirow{2}{*}{$\mathbf{p}$} & \multicolumn{2}{|c|}{ 95\% confidence interval } \\
\cline { 6 - 7 } & & & & \multicolumn{1}{|c|}{ Lower } & \multicolumn{1}{c|}{ Upper } \\
\hline $\mathrm{AR}(1)$ & $-0,270918$ & 0,117142 & $-2,31273$ & 0,023726 & $-0,504610$ & $-0,037226$ \\
\hline SAR(1) & 0,294691 & 0,118231 & 2,49250 & 0,015090 & 0,058826 & 0,530555 \\
\hline
\end{tabular}

Source: Authors' calculations 
Table 9. Projected quantities of drinking milk in Montenegro for the period January-December 2019 based on ARIMA $(1,1,0) \times(1,0,0)_{12}$

\begin{tabular}{|l|r|r|r|r|r|}
\hline \multirow{2}{*}{ Month } & \multirow{2}{*}{\begin{tabular}{c}
\multirow{2}{*}{$\begin{array}{c}\text { Projected } \\
\text { quantities }\end{array}$} \\
\end{tabular}} & \multicolumn{2}{c|}{$\begin{array}{c}\text { 90\% confidence interval of } \\
\text { projected volume }\end{array}$} & \multirow{2}{*}{$\begin{array}{c}\text { Standard } \\
\text { error of the } \\
\text { forecast }\end{array}$} & \multirow{2}{*}{\begin{tabular}{c}
\multirow{2}{*}{ Quantity } \\
collected
\end{tabular}} \\
\cline { 3 - 4 } & & Lower limit & \multicolumn{1}{c|}{ Upper limit } & \\
\hline January 2019 & $318.816,0$ & $230.918,8$ & $406.713,1$ & $52.720,2$ & 350.596 \\
\hline February 2019 & $330.860,1$ & $222.081,9$ & $439.638,3$ & $65.244,5$ & 358.905 \\
\hline Mach 2019 & $331.635,3$ & $201.989,7$ & $461.280,8$ & $77.760,6$ & 375.136 \\
\hline April 2019 & $315.690,8$ & $168.926,7$ & $462.455,0$ & $88.028,3$ & 340.145 \\
\hline May 2019 & $314.501,9$ & $152.215,6$ & $476.788,2$ & $97.338,4$ & 369.614 \\
\hline June 2019 & $310.727,8$ & $134.329,9$ & $487.125,7$ & $105.802,4$ & 341.675 \\
\hline July 2019 & $314.264,3$ & $124.790,3$ & $503.738,3$ & $113.645,4$ & 319.209 \\
\hline August 2019 & $305.039,7$ & $103.338,8$ & $506.740,6$ & $120.979,0$ & 318.597 \\
\hline September 2019 & $302.901,1$ & $89.672,4$ & $516.129,9$ & $127.893,4$ & 299.355 \\
\hline October 2019 & $308.434,9$ & $84.270,6$ & $532.599,2$ & $134.452,4$ & 296.372 \\
\hline November 2019 & $310.202,5$ & $75.611,8$ & $544.793,2$ & $140.706,1$ & \\
\hline December 2019 & $314.117,4$ & $69.544,4$ & $558.690,4$ & $146.693,4$ & \\
\hline
\end{tabular}

Source: Authors' calculations

Figure 3. Tendencies in production of observed and forecasted quantities of drinking milk

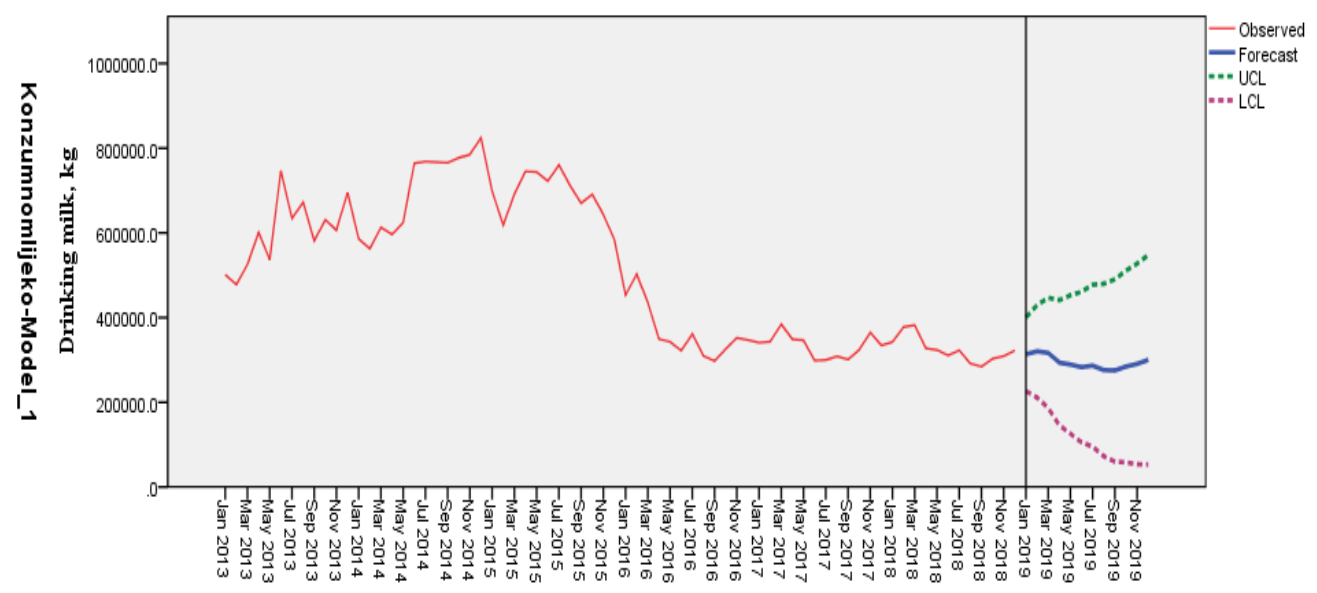

Source: Authors' calculations

Based on previous results, it can be concluded that the processing of milk in industrial plants is increasingly oriented towards the production of fermented dairy products, while the importance of drinking milk in the production structure of the dairy industry is declining since the beginning of 2015. On the other hand, family farms are not oriented whatsoever to the production of drinking milk, but primarily to the processing of raw milk into cheese and cream. Therefore, the placement of these dairy products in the market represents one of the important sources of income for family farms. The special importance of milk processing on family farms arises from the fact that approximately $85 \%-90 \%$ of the total milk produced in Montenegro is processed thereof. 
On the other hand, most of the products from family farms are within an unregistered zone, therefore it is difficult to monitor the quality of these products. It is necessary to introduce as many milk producing and processing farms as possible into the official control system for milk production and processing in order to ensure the health safety of products, given their representation in the nutrition. To this end, the Decree on Hygiene Requirements for Facilities and Premises Manufacturing Small Quantities of Primary Products for Human Consumption and Intended for Market, lays down requirements that must be implemented in order for products to be realized.

In order to improve milk processing on family farms, investments in relevant facilities and equipment are necessary. In this regard, the programme of institutional development and strengthening of agriculture - MIDAS was launched. The aim of the programme was to provide support to investments in agricultural farms with the aim of implementing rural development measures, increasing competitiveness in the agricultural market, introducing and strengthening European food production standards. The allocated funds are intended for the construction and reconstruction of facilities on agricultural farms, in addition to the procurement of equipment and mechanization, procurement of the basic herd, et cetera.

Programme was implemented in several stages, whereas support ranged from 50-60\% of the investment amount. The minimum amount of eligible investments was EUR 3,000 and maximum amount was EUR 70.000. Farmers who were registered in at least one of the registers or records of the Ministry of Agriculture and Rural Development of Montenegro or administrations within its jurisdiction were entitled to support. Legal entities also had a possibility of applying for grants provided that the activity they are engaged in is in the field of agriculture.

On the basis of available data, about EUR 12,8 million has been invested so far, and the total grant support is EUR 6,53 million. The number of applicants who received support under this programme is 669 . The total investment per applicant averages EUR 19.133,00 while the average grant amount per applicant is EUR 9.761,00. The largest number of investments, and consequently the amount of support, related to livestock production with just under EUR 9 million. If the territorial distribution of invested funds in livestock production is observed, the largest number of investments is allocated to the northern part of Montenegro in the amount of about EUR 5.6 million, or $43.75 \%$ of total investments. These funds were used by 458 farms and 14 legal entities. This indicates that the average investment per applicant in the northern part of Montenegro (which amounted to EUR 11.864,00) was lower than the national average. According to the livestock production sectors, the largest amount of investment is allocated to cattle, dairy and sheep farming.

In addition to this programme, agricultural farms and legal entities also had the opportunity to finance investments in milk processing through EU/IPA projects of institution building in agriculture and rural development in Montenegro (IPARD programme). Such significant investment support from a number of sources focused 
on milk processing activity indicates the importance attached to this activity in the territory of Montenegro.

Investing in milk processing facilities and equipment on family farms is an approach that may significantly improve the livestock business. Thus, the production of traditional cheeses for the diversification of production on family farms and the economic development of rural areas is also suggested by many authors (Braghieri et al., 2014; Roest, Menghi, 2000; Gerz, Dupont, 2006; Santini et al, 2013). The authors state that the production of traditional cheeses has contributed to retaining essential added value within the regions originating from, increasing the income of rural producers, increasing the price of products, attracting tourists, developing catering, accommodation services, reducing migration, increasing employment, etc. In the same way, processing of milk into indigenous cheeses (and other dairy products) at family farms in Montenegro could be a significant factor in their development.

\section{Conclusions}

Having analyzed situation in milk production, further efforts are needed to increase production. This statement arises from the fact that in the observed period stagnation was observed in terms of milkiness per animal unit as a result of poor racial composition and low productivity of dairy cows. In order to intensify milk production, it is necessary to work primarily on improving genetic potential of cattle, which should be accompanied by appropriate improvements in production technology. The production range of milk processing establishments not located on family farms is very narrow. The structure of production is dominated by fermented dairy products, where production of yoghurt is leading. The analysis of time series on the quantities of cow's milk collected, the fermented milk products obtained and drinking milk, revealed the presence of trend and seasonal components.

Alternatively, most of the milk produced is processed on family farms, with the production range being very narrow and referring primarily to cheese and cream. It is necessary for family farms to continue to make appropriate investments in milk processing facilities and equipment to enable diversification of production, the introduction of appropriate standards in production and the provision of health-safe dairy products.

\section{Conflict of interests}

The authors declare no conflict of interest.

\section{References}

1. Braghieri, A., Girolami, A., Riviezzi, A.M., Piazzolla, N., Napolitano, F. (2014). Liking of Traditional Cheese and Consumer Willingness to Pay, Italian Journal of Animal Science, 13, 155-162.

2. Deshmukh, S.,S., Paramasivam, R. (2016). Forecasting of milk production in India with ARIMA and VAR time series models, Asian J. Dairy \& Food Res, 35(1) 2016: 17-22, DOI: 10.18805/ajdfr.v35i1.9246 
3. Eurostat (2019). Production and utilization of milk on the farm - annual data, Retrieved from https://appsso.eurostat.ec.europa.eu/nui/show.do?dataset=apro mk farm\&lang=en (October 15, 2019)

4. Ferhan, A., Shah, H., Raza, I. and Saboor, A. (2011). Forecasting milk production in Pakistan, Pakistan J. Agric. Res. Vol 24 No. 1-4, 82-85

5. Gerz, A., Dupont, F. (2006). Comte cheese in France: Impact of a geographical indication on rural development. Origine-based products, lessons for pro-poor market development, Bulletin 372, Amsterdam, Netherlads, 75 pp.

6. Gujarati, D.N. (2003). Basic Econometrics, McGraw-Hill Higher Education, New York, United States

7. Ivanović, L. (2018). Possibilities for development of extensive forms of livestock production in Serbia. Doctoral thesis. Faculty of Agriculture, University of Novi Sad [in Serbian:Ivanović, L. (2018). Mogućnosti razvoja ekstenzivnih oblika stočarske proizvodnje u Srbiji. Doktorska disertacija. Poljoprivredni fakultet, Univerzitet u Novom Sadu]

8. Jovanović, M., Despotović, Aleksandra, Bulatović, B. (2001). Changes of the milk and dairy products consumption with changes of the income, Agriculture and forestry, Vol 47 (1-2), Podgorica, 101-114 [in Serbian: Jovanović, M., Despotović Aleksandra, Bulatović, B. (2001): Promjena potrošnje mlijeka i mliječnih proizvoda sa promjenom dohotka, Poljoprivreda $i$ šumarstvo, Vol 47 (1-2), Podgorica, 101-104]

9. Kovačić, Z. (1995). Time Series Analysis, Faculty of Economics, University of Belgrade, Belgrade [in Serbian: Kovačić, Z. (1995). Analiza vremenskih serija, Ekonomski fakultet, Univerzitet u Beogradu, Beograd]

10. Mihailović, Šumadinka, Vukelić, Nataša, Novković, N., Mutavdžić, Beba (2019). Vegetable prices in serbia - tendencies and forecasting, Economics of Agriculture, Year 66, No. 2, Belgrade, 485-498, doi:10.5937/ekoPolj1902485S

11. Ministry of Agriculture and Rural Development (2015). Agriculture and Rural Development Strategy 2015-2020, Podgorica, 1-65 [in Serbian: Ministarsrvo poljoprivrede i ruralnog razvoja (2015). Strategija razvoja poljoprivrede i ruralnih područja 2015-2020, Podgorica, 1-65]

12. Ministry of Agriculture and Rural Development, (2018). National Programme for Improving the Quality of Raw Milk with a Plan for the Management of Nonconforming Raw Milk, Podgorica, 4-25 [in Serbian: Ministarstvo poljoprivrede i ruralnog razvoja, (2018). Nacionalni program za unapređenje kvaliteta sirovog mlijeka sa planom za postupanje sa neusaglašenim sirovim mlijekom, Podgorica, 4-25]

13. Mladenović, Z. \& Nojković, A. (2015). Applied time series analysis, Faculty of Economics, University of Belgrade, Belgrade [in Serbian: Mladenović, Z. \& Nojković, A. (2015). Primenjena analiza vremenskih serija, Ekonomski fakultet Univerziteta u Beogradu, Beograd] 
14. Mutavdžić, Beba, Novković, N., Vukelić, Nataša, Radojević, V. (2016). Analysis and prediction of prices and price partyes of corn and wheat in Serbia, Journal on Processing and Energy in Agriculture 20 (2016) 2, 106-108, UDK: 338:582.542.11

15. Novković, N., Mutavdzic, Beba, Somogy, S. (2010). Vegetable Prediction Models, School of Business, Issue 3/2010, 41-49, UDC 635.1/.8: 005.521 (497.113) [in Serbian: Novković, N., Mutavdžić, Beba, Šomođi, Š. (2010). Modeli za predviđanje u povrtarstvu, Škola biznisa, broj 3/2010, 41-49, UDC 635.1/.8:005.521(497.113)]

16. Perišić, P., Topisirović, G., Pešić-Mikulec, Dragana, Puja, P. (2011). Analysis of milk production factors at selected farms in Zlatibor District, Agricultural Engineering, No. 4, Faculty of Agriculture Zemun, Belgrade, 11-20 [in Serbian: Perišić, P., Topisirović, G., Pešić-Mikulec, Dragana, Puđa, P. (2011). Analiza faktora proizvodnje mleka na odabranim gazdinstvima Zlatiborskog okruga,Poljoprivredna tehnika, broj 4, Poljoprivredni fakultet Zemun, Beograd, 11-20]

17. Roest de K., Menghi, A. (2000): Reconsidering 'Traditional' Food: The Case of Parmigiano Reggiano Cheese. Sociologia Ruralis, Vol 40, No. 4, 439-451.

18. Safa Abdelgadier, H., Hag Hamad, A., Abdelateif Hassan, I., Khalid Salih, M.M. (2018). Milk Production - Forecasting in Khartoum State, Sudan, IJRDO - Journal of Agriculture and Research, Volume-4, Issue-12, 8-13

19. Sanchez, L., Cabanas, G., Abad, Y., and Torres, V. (2014). Use of ARIMA models for predicting milk production. Case study in UBPC "Maniabo", Las Tunas, Cuban Journal of Aricultural Science, Volume 48, Number 3, 213-218 UDK: 338:582.542.11

20. Sankar, T.J., Prabakaran, R. (2012). Forecasting milk production in Tamilnadu, International Multidisciplinary Research Journal, 2 (1), 10-15

21. Santini, F., Guri, F., Gomez, S. (2013): Labeling of agricultural and food products of mountain farming. JRC Scientific and policy reports, European Commision Joint Research, Centre institute for Prospective Technological Studies, Luxembourg, 1-154 pp.

22. Statistical Office of Montenegro - Monstat - (2016). Structure of agricultural farms in 2016, Podgorica, Retrieved from https:/www.monstat.org (September 16, 2019) [in Serbian: Uprava za statistiku Crne Gore - Monstat - (2016). Struktura poljoprivrednih gazdinstava u 2016. godini, Podgorica, Retrieved from https:// www.monstat.org (September 16, 2019)]

23. Statistical Office of Montenegro - Monstat - (2018). Numerous livestock and poultry status, milk, wool and egg production in Montenegro in 2018, Podgorica, Retrieved from https://www.monstat.org (December 9, 2019) [in Serbian: Uprava za statistiku Crne Gore - Monstat - (2018). Brojno stanje stoke i živine, proizvodnja mlijeka, vune i jaja u Crnoj Gori u 2018. godini, Podgorica, Retrieved from https:// www.monstat.org (December 9, 2019)]

24. Statistical Office of Montenegro - Monstat - (2019). Statistical Yearbook 2019, Podgorica, 101-118 [in Serbian: Uprava za statistiku Crne Gore - Monstat (2019). Statistički godišnjak 2019, Podgorica, 101-118] 